\title{
Desain Ipal Komunal Limbah Domestik Perumahan Sukolilo Dian Regency dengan Teknologi Constructed Wetland Dandy Prakoso*, Bieby Voijant Tangahu*
}

*Enviromental Engineering Department, Faculty Civil of Engieering and planning, Institut Teknologi Sepuluh Nopember (ITS), Jl. Arief Rahman Hakim, Surabaya 60111, Indonesia

\begin{abstract}
Constructed wetland merupakan sistem pengolahan terencana atau terkontrol yang telah didesain dan dibangun menggunakan proses alami yang melibatkan vegetasi, media, dan mikroorganisme untuk mengolah air limbah domestik. Constructed wetland cocok untuk diterapkan di perumahan, sehingga teknologi ini cocok menjadi alternatif pengolahan limbah domestik. Perumahan Sukolilo Dian Regency (SDR) merupakan salah satu perumahan yang belum memiliki IPAL untuk mengolah greywater, sehingga teknologi ini bisa diterapkan di perumahan ini untuk meningkatkan kualitas sanitasi lingkungan. Perencanaan sistem IPAL di Perumahan SDR mempertimbangkan aspek kuantitas dan kualitas air limbah domestik yang dihasilkan setiap harinya. Kualitas air limbah domestik menunjukkan nilai COD 320 mg/L; BOD 123 mg/L; dan TSS $60 \mathrm{mg} / \mathrm{L}$. Sedangkan kuantitas air limbah menunjukan $453 \mathrm{~m}^{3} /$ hari. Kemudian dilakukan analisis perhitungan masing-masing unit IPAL yang akan direncanakan di perumahan SDR agar sesuai dengan kriteria baku mutu pergub jatim no. 72 tahun 2013. Sistem IPAL direncanakan terdiri dari unit bak ekualisasi, Subsurface Flow Constructed Wetland dengan tanaman cattail, dan kolam indikator. Hasil perencanaan menunjukkan efisiensi pengolahan seluruh sistem untuk COD, BOD, dan TSS masing-masing sebesar 86\%, 80\%, dan 46\%, dengan efisiensi tersebut effluent limbah cari IPAL telah memenuhi baku mutu yang ditentukan. Biaya investasi seluruh sistem constructed wetland diperkirakan sebesar Rp 5.926.417.781. Perencanaan ini menghasilkan panduan untuk operasional dan perawatan.
\end{abstract}

Kata kunci: constructed wetland; cattail sp; greywater; IPAL perumahan

\section{PENDAHULUAN}

$\mathrm{P}$ ertumbuhan penduduk di Kota Surabaya memberikan dampak terhadap penurunan daya dukung lingkungan. Salah satu dampak dari pertumbuhan penduduk ini adalah meningkatnya jumlah air limbah domestik. Hal ini membuat perlunya dibangun Instalasi Pengolahan Air Limbah (IPAL). Kondisi lingkungan di Surabaya membuat pengolahan air limbah domestik sebaiknya dilakukan secara setempat. Pengelolaan air limbah domestik secara setempat menggunakan teknologi lebih sederhana dan biaya yang lebih rendah dibandingkan dengan sistem terpusat [1]. Pengelolaan air limbah domestik secara setempat cocok diterapkan untuk kawasan perumahan.

Perumahan Sukolilo Dian Regency merupakan salah satu perumahan di Kota Surabaya. Limbah blackwater di perumahan ini diolah dengan tangki septik yang terdapat di masing-masing rumah, sedangkan limbah greywater dibuang langsung ke selokan. Menurut UU No. 32 Tahun 2009, setiap orang diperbolehkan membuang limbah ke media lingkungan hidup dengan syarat memenuhi baku mutu lingkungan hidup. Dari latar belakang tersebut maka diperlukan perencanaan unit Instalasi Pengolahan Air Limbah (IPAL) di Perumahan Sukolilo Dian Regency.

Teknologi constructed wetland dapat diterapkan sebagai teknologi pengolahan limbah greywater di perumahan atau domestik [2]. Constructed wetland merupakan sistem pengolahan terencana atau terkontrol yang telah didesain dan dibangun menggunakan proses alami yang melibatkan vegetasi, media, dan mikroorganisme untuk mengolah air limbah [3]. Prinsip pengolahan air limbah dengan constructed wetland dengan mengalirkan air limbah di bawah media sehingga limbah akan diserap melalui akar tanaman. Constructed wetland merupakan metode pengolahan air limbah yang mudah dalam perawatan dan memiliki nilai efisiensi yang cukup tinggi [4]. Constructed wetland dapat mendegradasi zat organik, nitrogen, dan phosphorus secara serentak [5], sehingga constructed wetland mampu yang mengurangi kandungan nutrien secara signifikan.

Penggunaan constructed wetland dapat menjadi alternatif pengolahan air limbah domestik skala perumahan. Keuntungan yang diperoleh dari sistem ini adalah memperoleh nilai efisiensi yang tinggi dari pengolahan limbah domestik skala perumahan dan memperoleh desain IPAL komunal yang memiliki nilai estetika.

\section{GAMBARAN UMUM WILAYAH PERENCANAAN}

Perencanaan ini dilakukan di Perumahan Sukolilo Dian Regency yang terletak di Surabaya Timur, tepatnya berada di Jalan Sukolilo Kasih no. 20 Kelurahan Keputih Kecamatan Sukolilo. Perumahan ini terdiri atas rumah berlantai 1 dan 2 lantai dengan rata-rata luas tanah setiap rumah sekitar $90 \mathrm{~m}^{2}$ hingga $200 \mathrm{~m}^{2}$. Setiap rumah di Perumahan Sukolilo Dian Regency memiliki septic tank untuk mengolah limbah blackwater. Air effluent dari septic tank langsung di buang ke selokan/ drainase bersama dengan greywater. IPAL dengan teknologi constructed wetland akan didesain di lahan kosong dengan luas lahan tersedia $2100 \mathrm{~m}^{2}$.

\footnotetext{
* Dandy Prakoso. Tel.: +62-857-14175906

E-mail address: dandyprakoso3@gmail.com
} 


\section{URAIAN PERENCANAAN}

\section{A. Penentuan Jumlah Sampel}

Sampel merupakan banyaknya masyarakat dari populasi yang digunakan sebagai sampel. Tujuan dari penentuan jumlah sampel untuk mendapatkan hasil yang representatif dari suatu populasi. Penentuan jumlah sampel dapat dihitung berdasarkan persamaan Slovin:

$\mathrm{n}=\frac{n}{1+(P x D)}$

Dimana:

$\mathrm{n}=$ Jumlah sampel

$\mathrm{P}=$ Jumlah populasi

$\mathrm{D}=$ Standar deviasi

\section{B. Perhitungan Unit Constructed Wetland}

Dimensi unit constructed wetland dipengaruhi oleh faktor utama yaitu seberapa besar efisiensi pengolahan yang diingingan. Efisiensi dipengaruhi oleh faktor utama yaitu seberapa lama air limbah berada pada unit constructed wetland atau biasa disebut dengan waktu tinggal hidraulik (HRT).

Menurut [6] perhitungan waktu detensi di reaktor constructed wetland dengan pendekatan removal BOD/COD dan temperatur, dengan rumus sebagai berikut:

- Efisiensi pengolahan BOD

$$
\mathrm{R}_{\mathrm{BOD}}=\frac{C_{\text {in }}-C_{\text {out }}}{C_{\text {in }}}
$$

Dimana: $\mathrm{R}_{\mathrm{BOD}} \quad=$ Efisiensi pengolahan $\mathrm{BOD}$

$\mathrm{C}_{\mathrm{In}} \quad=$ Konsentrasi influent $(\mathrm{mg} / \mathrm{L})$

$\mathrm{C}_{\text {out }} \quad=$ Konsentrasi effluent $(\mathrm{mg} / \mathrm{L})$

Waktu detensi pengolahan BOD

$$
\mathrm{R}_{\mathrm{BOD}}=\frac{H R T}{(22,8 / T)+H R T}
$$

Dimana: HRT = Hydraulic Residence Time (hari)

$\mathrm{T}=$ Temperature $\left({ }^{0} \mathrm{C}\right)$

- Efisiensi pengolahan COD

$$
\mathrm{R}_{\mathrm{COD}}=\frac{C_{\text {in }}-C_{\text {out }}}{C_{\text {in }}}
$$

$$
\begin{array}{cl}
\text { Dimana: } & \mathrm{R}_{\mathrm{COD}} \\
\mathrm{C}_{\mathrm{In}} & =\text { Efisiensi pengolahan COD } \\
\mathrm{C}_{\text {out }} & =\text { Konsentrasi influent }(\mathrm{mg} / \mathrm{L}) \\
&
\end{array}
$$

- Waktu detensi pengolahan COD

$$
\begin{array}{cl}
\mathrm{R}_{\mathrm{COD}}= & \frac{H R T}{(15 / T)+H R T} \\
\text { Dimana: } \mathrm{HRT} & =\text { Hydraulic Residence Time (hari) } \\
\mathrm{T} & =\text { Temperature }\left({ }^{\circ} \mathrm{C}\right)
\end{array}
$$

\section{Perhitungan Evapotranspirasi dan Presipitasi}

Pada unit SSFCW terjadi reaksi evapotranspirasi yang mengakibatkan berkurangnya kuantitas air dalam unit ini. Berkurangnya kuantitas air dikarenakan tanaman memerlukan air dalam jumlah tertentu untuk reaksi fotosintesis. Besarnya nilai evapotranspirasi suatu tanaman dapat dihitungan dengan rumus sebagai berikut:

Qe = Ex As

Dimana:

Qe = debit akitbat evapotranspirasi $\left(\mathrm{m}^{3} / \mathrm{hari}\right)$

$\mathrm{E} \quad=$ laju evapotranspirasi tanaman $(\mathrm{mm} / \mathrm{hari})$ 
As $\quad=$ luas permukaan tanaman $\left(\mathrm{m}^{2}\right)$ berikut:

Pada saat hujan atau presipitasi perhitungan peningkatan debit pada unit SSFCW dapat dihitung dengan rumus sebagai

$\mathrm{Q}_{\mathrm{p}}=\mathrm{P} \times \mathrm{As}$

Dimana:

$\mathrm{Q}_{\mathrm{p}} \quad=$ debit akibat presipitasi $\left(\mathrm{m}^{3} /\right.$ hari $)$

$\mathrm{P} \quad=$ hujan harian maksimum $(\mathrm{mm} /$ hari $)$

As $\quad=$ luas permukaan tanaman $\left(\mathrm{m}^{2}\right)$

D. Perhitungan Kehilangan Tekan

- Perhitungan headloss pada pipa bertekanan dihitung menggunakan rumus Hazzen-William, dengan perhitungan sebagai berikut:

$h f=\left[\frac{Q}{0,2785 \cdot C \cdot D^{2,63}}\right]^{1,85} L$

Dimana: hf = headloss $(\mathrm{m})$

$\mathrm{Q} \quad=\operatorname{debit}\left(\mathrm{m}^{3} / \mathrm{s}\right)$

$\mathrm{C}=$ koefisien kekasaran

$\mathrm{L} \quad=$ panjang pipa $(\mathrm{m})$

- Perhitungan headloss pada saluran terbuka dihitung menggunakan rumus manning, dengan perhitungan sebagai berikut:

$\mathrm{S}=\left[\frac{n v P}{A^{2 / 3}}\right]^{2}$

Dimana: $\mathrm{S} \quad=$ slope

A $\quad$ luas penampang basah $\left(\mathrm{m}^{2}\right)$

$\mathrm{n} \quad=$ koefisien kekasaran

$\mathrm{P} \quad=$ keliling basah $(\mathrm{m})$

$\mathrm{v} \quad=\operatorname{kecepatan}(\mathrm{m} / \mathrm{s})$

- Headloss pada aksesoris dihitung menggunakan rumus Hazzen-William, dengan perhitungan sebagai berikut:

$h f=k\left[\frac{k v^{2}}{2 g}\right]$

Dimana:

hf $=$ headloss $(\mathrm{m})$

$\mathrm{K}=$ jumlah aksesoris

$\mathrm{V} \quad=$ kecepatan di dalam aksesoris $(\mathrm{m} / \mathrm{s})$

$\mathrm{g} \quad=$ percepatan gravitasi $\left(9,81 \mathrm{~m} / \mathrm{s}^{2}\right)$

- Headloss pada media SSFCW dihitung dengan rumus sebagai berikut [7]:

$h f=\frac{Q \cdot A s}{K \cdot h \cdot W^{2}}$

Dimana:

hf $\quad=$ headloss $(\mathrm{m})$

$\mathrm{Q} \quad=\operatorname{debit}\left(\mathrm{m}^{3} / \mathrm{s}\right)$

As $\quad=$ Permukaan constructed wetland $\left(\mathrm{m}^{2}\right)$

$\mathrm{K} \quad=$ konduktifitas hidraulik $(\mathrm{m} / \mathrm{d})$

$\mathrm{W} \quad=$ lebar constructed wetland $(\mathrm{m})$

$\mathrm{h} \quad=$ kedalaman muka air $(\mathrm{m})$

E. Perhitungan Porositas Media

Perhitungan porositas media bertujuan untuk mengetahui volume yang dibutuhkan media dalam suatu unit IPAL. Adapun perhitungan porositas media sebagai [8]:

$\mathrm{n}=\frac{V_{p}}{V} x 100 \%$

$\begin{array}{cl}\text { Dimana: } \mathrm{n} & =\text { Porositas }(\%) \\ \mathrm{Vp} & =\text { Volume poros }\left(\mathrm{m}^{3}\right) \\ \mathrm{V} & =\text { Volume total media }\left(\mathrm{m}^{3}\right)\end{array}$ 


\section{HASIL DAN PEMBAHASAN}

\section{A. Kualitas Air Limbah}

Kualitas air limbah domestik di Perumahan Sukolilo Dian Regency diketahui dari hasil analisis sampel air limbah yang diambil di lapangan. Sampling dilakukan sebanyak 4 kali untuk mengetahui tingkat fluktuasi kualitas air limbah tersebut. Metode sampling yang digunakan adalah grab sampling dan pengumpulan sampel dilakukan secara conposite. Hasil analisis kualitas air limbah sebagai berikut:

TSS $=60 \mathrm{mg} / \mathrm{L}$

$\mathrm{COD}=320 \mathrm{mg} / \mathrm{L}$

$\mathrm{BOD}=123 \mathrm{mg} / \mathrm{L}$

\section{B. Kuantitas Air Limbah}

Kuantitas air limbah domestik diperoleh dari sampling penggunaan air bersih (PDAM) warga. Pemakaian air PDAM diketahui dari nomor pelanggan tiap rumah untuk kemudian di cek melalui website PDAM. Jumlah responden yang ditentukan dengan persamaan (1) dan diperoleh hasil 35 responden sebagai sampel.

Setelah diketahui jumlah responden yang diperlukan dapat diketahui berapa kuantitas pemakaian air PDAM $\mathrm{m}^{3} /$ org.hari. Diperoleh hasil perhitungan pemakaian air PDAM rata-rata sebesar 0,190 $\mathrm{m}^{3} /$ org.hari. Selanjutnya kuantitas air limbah domestik diketahui $80 \%$ dari pengguanaan air PDAM berdasarkan survey langsung di lapangan, dan diketahui debit air limbah harian sebesar 0,151 m³/org.hari. Perumahan SDR memiliki kapasitas maksimal $600 \mathrm{KK}$ dan setiap KK terdiri atas 5 orang, sehingga bisa diperoleh total debit sebagai berikut :

Debit harian $\quad=0,151 \mathrm{~m}^{3} /$ org.hari $\mathrm{x} 3000$ orang

$$
=453 \mathrm{~m}^{3} / \text { hari }
$$

\section{Analisis Perencanaan dan Kesetimbangan}

Perencanaan IPAL di Perumahan Sukolilo Dian Regency direncanakan menggunakan Subsurface Flow Constructed Wetland $(S S F C W)$ dengan berbagai pertimbangan aspek teknis dan finansial. Beberapa kelebihan pengolahan air limbah domestik menggunakan Subsurface Flow Constructed Wetland (SSFCW) dibandingkan dengan unit lain seperti Free Water Surface Constructed Wetland (FWSCW) lain dapat dilihat pada Tabel 1.

Tabel 1. Alternatif perbandingan unit IPAL

SSFCW $F W S C W$

- Mudah dan murah dalam operasional

- Jenis tanaman mudah diganti-ganti

- Tidak menimbulkan bau dan sarang nyamuk karena tertutup media

- Tidak adanya media atas penyangga tanaman, membuat fluktuasi termal pada air limbah menjadi tinggi

- Pengaliran air limbah dibawah media memberikan proteksi termal yang - Peletakan tanaman mudah berubah akibat aliran air lebih baik terhadap fluktuasi suhu

Sumber: Wallace, 2006

Perbandingan di atas menunjukkan tipe Subsurface Flow Constructed Wetland (SSFCW) lebih cocok diterapkan dalam perencanaan ini. Kesetimbangan massa polutan dari seluruh pengolahan di sistem IPAL dapat dilihat pada Gambar 1.

Pada unit SSFCW terjadi reaksi evapotranspirasi yang mengakibatkan berkurangnya kuantitas air dalam unit ini, hal ini dikarenakan tanaman memerlukan air dalam jumlah tertentu untu reaksi fotosintesis. Sedangkan, pada saat hujan atau presipitasi perhitungan peningkatan debit akibat presipitasi pada unit SSFCW. Kesetimbangan massa air akibat pengaruh presipitasi dan evapotranspirasi dihitung dengan rumus pada persamaan dan ditampilkan pada Gambar 2 dan 3.

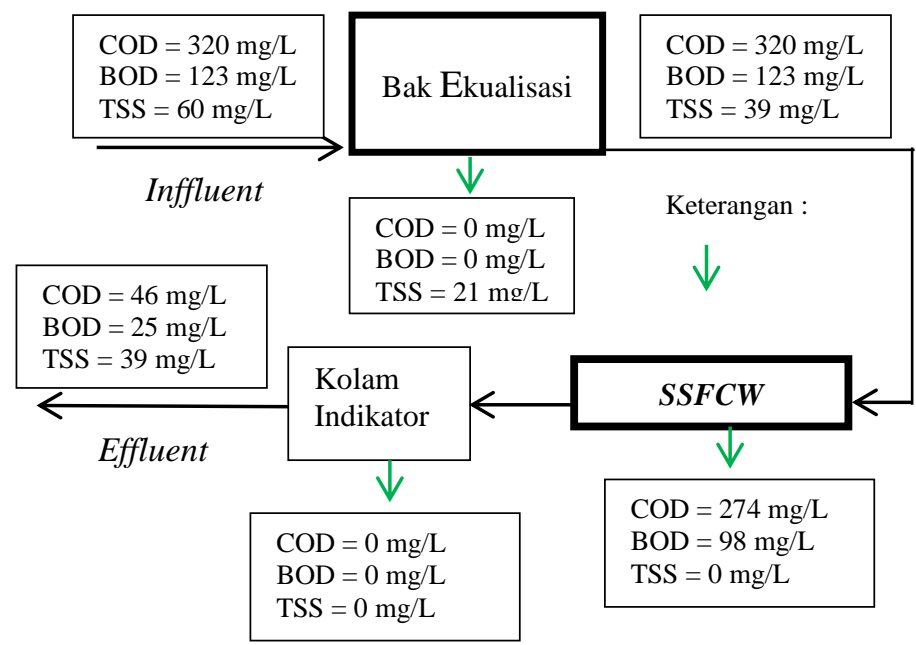


Gambar 1. Mass balance polutan dalam sistem IPAL

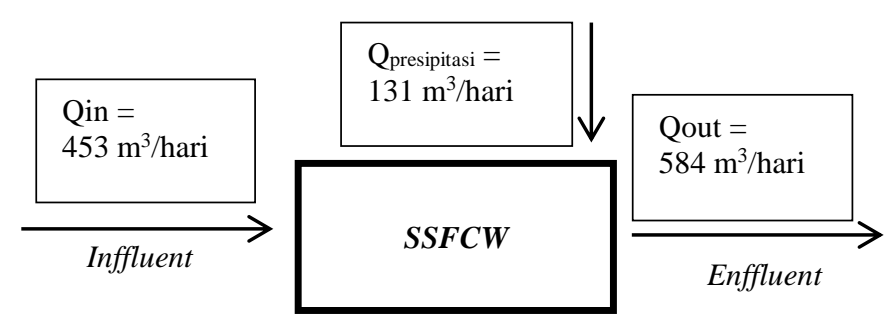

Gambar 2. Water balance presipitasi

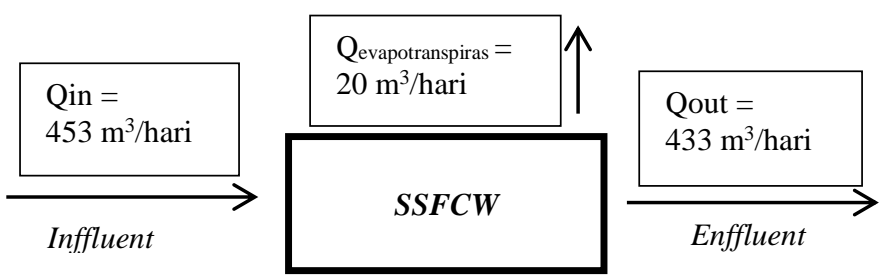

Gambar 3. Water balance evapotranspirasi

D. Perencanaan Unit-unit Pengolah Air Limbah

Perencanaan IPAL terdiri atas bak ekualisasi, bangunan Subsurface Flow Constructed Wetland, bak penampung akhir, dan sistem pengaliran.

1) Perencanaan Pompa Pengumpan

Pompa pengumpan digunakan untuk menaikan elevasi muka air dari manhole terakhir Sistem Penyaluran Air Limbah

(SPAL) ke bak ekualisasi d sistem IPAL, sistem pemompaan dapat dilihat pada Gambar 4.

Berdasarkan gambar dapat diketahui kebutuhan pemompaan dari sumur pengumpul ke bak ekualisasi, sebagai berikut:

Total kebutuhan head $=4 \mathrm{~m}$

Dari perhitungan tersebut diperoleh tipe pompa sebagai berikut:

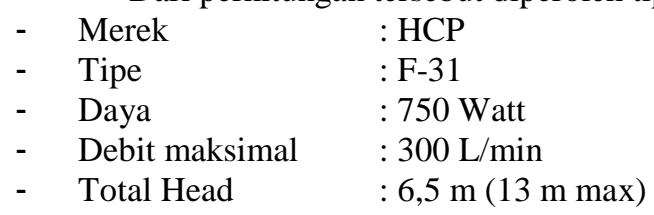

\section{2) Perencanaan Bak Ekualisasi}

Bak ekualisasi difungsikan meratakan beban air limbah domestik dari perumahan dan sebagai bak pengendap TSS. Unit ini direncanakan berbentuk persegi panjang dengan pengaliran dari bak ekualisasi ke unit berikutnya (SSFCW) menggunakan pemompaan. Adapun perhitungan bak ekualisasi menggunakan faktor pemakaian sebagai pembagian debit tiap jam dalam 1 hari, faktor pemakaian maks sebesar 1,5 dan faktor pemakaian terkecil 0,3. Berdasarkan faktor pemakaian tersebut diperoleh volume bak dengan waktu tinggal 2 jam.

Pengaliran dari bak ekualisasi ke unit berikutnya menggunakan pompa dengan spesifikasi yang sama dengan pompa feed, karena nilai head statis yang lebih rendah dari sistem sebelumnya sehingga pompa dengan spesifikasi yang sama mampu untuk menyalurkan air ke unit berikutnya.

Dari seluruh perhitungan diperoleh dimensi bak ekualisasi dan spesifikasi pompa sebagai berikut:

- Dimensi bak ekualisasi:

$$
\begin{array}{lll}
\text { - } & \text { Volume efektif } & : 32 \mathrm{~m}^{3} \\
\text { - } & \text { Luas efektif } & : 16 \mathrm{~m}^{2} \\
\text { - } & \text { Kedalaman air } & : 2 \mathrm{~m} \\
\text { - } & \text { Ruang bebas } & : 0,5 \mathrm{~m} \\
\text { - } & \text { Panjang efektif } & : 4 \mathrm{~m} \\
\text { - } & \text { Lebar efektif } & : 4 \mathrm{~m} \\
\text { - } & \text { Spesifikasi pompa: } \\
\text { - } & \text { Merek } & : \text { HCP } \\
\text { - Tipe } & : \text { F-31 } \\
\text { - Daya } & : 750 \text { Watt }
\end{array}
$$


- Debit maksimal : $300 \mathrm{~L} / \mathrm{min}$

- Total Head $\quad: 6,5 \mathrm{~m}(13 \mathrm{mmax})$

Gambar denah dan potongan melintang bak ekualisasi dapat dilihat pada Gambar 5.

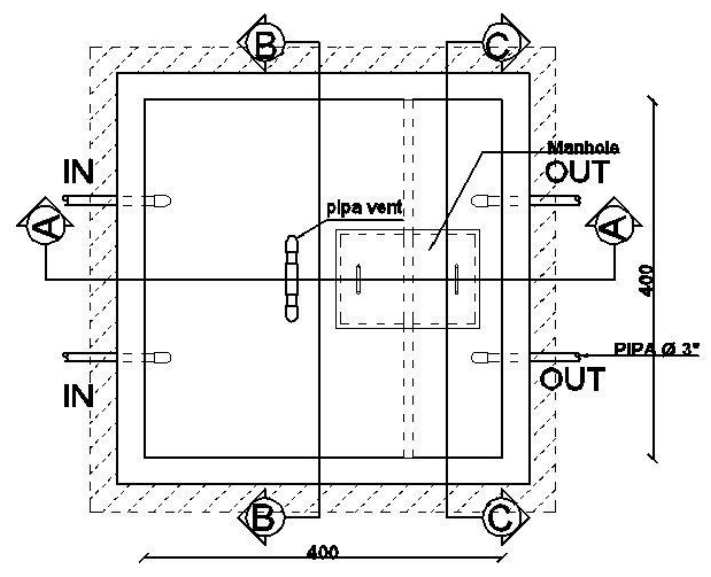

a

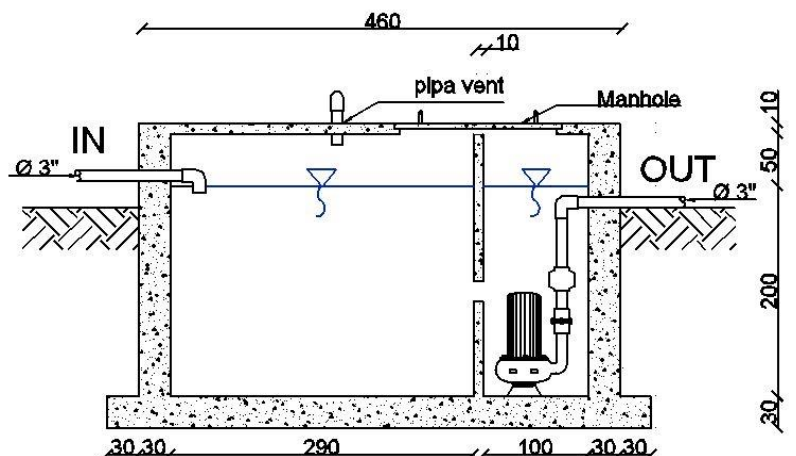

b

Gambar 5. (a) Denah Bak Ekualisasi; (b) Potongan A-A bak ekulisasi

\section{3) Perencanaan Unit Subsurface Flow Constructed Wetland (SSFCW)}

Unit Subsurface Flow Constructed Wetland (SSFCW) direncanakan berbentuk persegi panjang dan terbagi atas beberapa kompartmen. Pembagian kompartmen bertujuan untuk meratakan persebaran air dan memudahkan dalam perawatan unit SSFCW. Waktu detensi (HRT) di unit SSCW selama 3 hari. Tanaman yang digunakan pada unit adalah cattail dengan kerapatan penanaman dalam $1 \mathrm{~m}^{2}$ terdapat 5 tanaman cattail [9]. Media yang digunakan pada unit ini terdiri dari bioball yang digunakan sebagai media melekatnya akar yang tercelup air limbah dan media gravel sebagai penyangga atas yang berfungsi menyangga sisi tanaman yang tidak tercelup air.

Berdasarkan perhitungan teoritis diperoleh spesifikasi unit SSFCW sebagai berikut:

- P kompartmen efektif : $: 520 \mathrm{~m}$

- L kompartmen efektif : :3,25 m

- P bangunan efektif $\quad: 65 \mathrm{~m}$

- L bangunan efektif $\quad: 26 \mathrm{~m}$

- Kedalaman air $\quad: 1 \mathrm{~m}$

- Freeboard : :0,5 m

- Volume media (bioball) : $1685 \mathrm{~m}^{3}$

- Volume media (gravel) : $843 \mathrm{~m}^{3}$

Gambar denah dan potongan melintang unit SSFCW dapat dilihat pada Gambar 6 dan 7.

\section{4) Perencanaan Unit Kolam Indikator}

Unit bak penampung digunakan untuk menampung air olahan dari SSFCW sebelum dibuang ke badan air. Pada unit ini tidak terdapat pengolahan dan ditentukan waktu detensi pada kolam ini yaitu 0,01 hari. Maka, diperoleh dimensi kolam indikator sebagai berikut:

$\begin{array}{ll}-\quad \text { Volume efektif } & : 5,7 \mathrm{~m}^{3} \\ -\quad \text { Luas Efektif } & : 3,8 \mathrm{~m}^{2} \\ -\quad \text { Kedalaman air } & : 1,5 \mathrm{~m} \\ -\quad \text { Jumlah unit } & : 2 \mathrm{unit} \\ -\quad \text { Panjang tiap unit } & : 2 \mathrm{~m} \\ -\quad \text { Lebar tiap unit } & : 1 \mathrm{~m} \\ -\quad \text { Ketebalan tembok } & : 0,3 \mathrm{~m} \\ -\quad \text { Freeboard } & : 0,5 \mathrm{~m}\end{array}$

\section{5) Perencanaan Sistem Pengaliran dan Profil Hidrolis}

Sistem pengaliran antar unit menggunakan sistem saluran terututup berupa pipa. Penentuan dimensi pipa ditentukan berdasarkan nilai headloss serendah mungkin namun dengan diameter pipa yang tidak terlalu besar, supaya tidak diperlukan nilai slope yang tinggi pada pipa dan mendapatkan pipa dengan harga seefisien mungkin. Perhitungan headloss meliputi perhitungan headloss mayor dan minor pada sistem IPAL. Adapun perhitungan seluruh headloss dalam sistem IPAL ditampilkan dalam Tabel 2. 
Tabel 2. Perhitungan headloss pada sistem IPAL

\begin{tabular}{cccc}
\hline \hline Segmen & HF mayor & Hf minor & Hf total \\
\hline A1 & 0,10 & 0,65 & 0,74 \\
A2 & 0,04 & 0,38 & 0,42 \\
A3 & 0,03 & 0,15 & 0,18 \\
\hline \hline
\end{tabular}

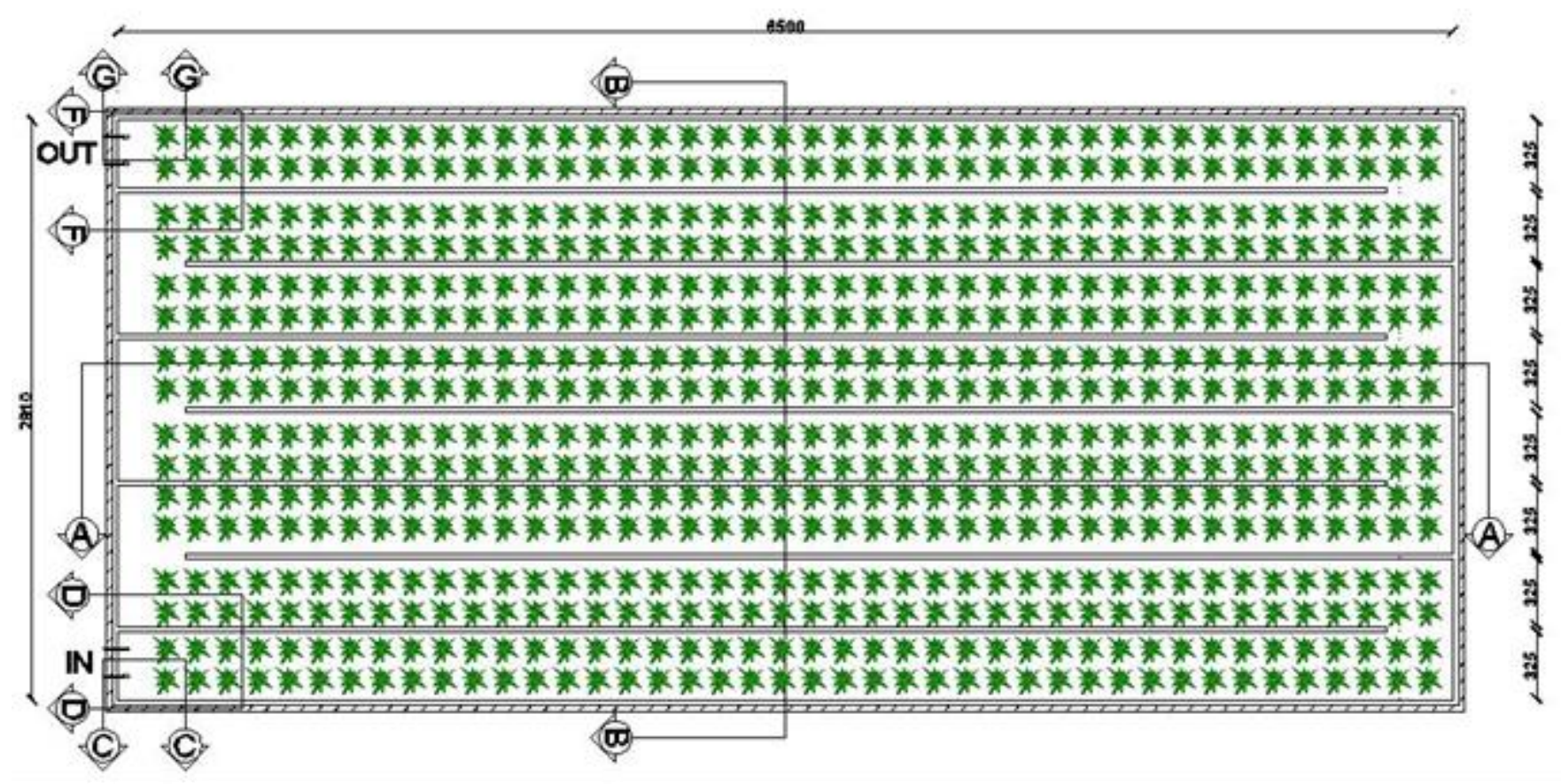

Gambar 6. Denah unit SSFCW

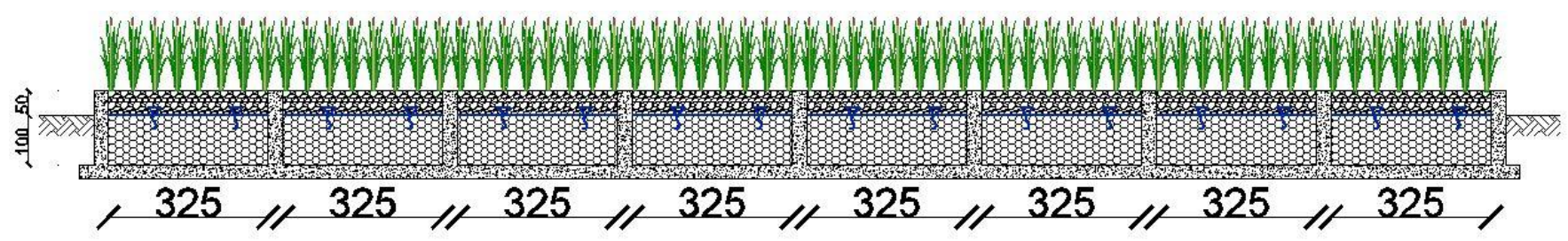

Gambar 7. Potongan B-B unit SSFCW

V. RENCANA ANGGARAN BIAYA

Rencana anggaran biaya (RAB) digunakan untuk menentukan jumlah investasi yang diperlukan untuk pembangunan IPAL. RAB dihitung berdasarkan volume pekerjaan dan Harga Satuan Pokok Kegiatan (HSPK) Kota Surabaya tahun 2015 dikalikan volume pekerjaan. Hasil perhitungan RAB ditampilkan dalam Tabel 3.

Tabel 3. RAB IPAL

\begin{tabular}{cll}
\hline \hline No & \multicolumn{1}{c}{ Uraian Pekerjaan } & \multicolumn{1}{c}{ Jumlah Harga } \\
\hline 1. & Pekerjaan Persiapan & Rp 20.496.200 \\
2. & Pekerjaan Beton dan Pasangan & Rp 3.128.594.249 \\
3. & Pekerjaan Finishing & Rp 35.971.500 \\
4. & Pekerjaan komponen penunjang IPAL & Rp 2.341.247.800 \\
\hline \multicolumn{2}{c}{ Total } & Rp 5.526.309.749 \\
\hline \hline
\end{tabular}

\section{KESIMPULAN}

Kesimpulan dari desain IPAL di perumahan SDR sebagai berikut:

1. Perencanaan IPAL di Perumahan SDR memerlukan lahan total sekitar $1800 \mathrm{~m}^{2}$, teridiri atas bak ekualisasi $\left(21 \mathrm{~m}^{2}\right), \mathrm{SSFCW}$ $\left(1685 \mathrm{~m}^{2}\right)$, dan kolam indikator $\left(4 \mathrm{~m}^{2}\right)$.

2. IPAL SSFCW memiliki efisiensi untuk mengolah COD, BOD, dan TSS masing sebesar $85 \%, 80 \%$, dan $46 \%$. 
3. Perencanaan IPAL di Perumahan SDR memerlukan biaya total sebesar Rp 5.926.417.781,00.

\section{DAFTAR PUSTAKA}

[1] A. Nurhidayat and J. Hermana, "Strategi Pengelolaan Air Limbah Domestik Dengan Sistem Sanitasi Skala Lingkungan Berbasis Masyarakat Di Kota Batu Jawa Timur," in Prosiding Seminar Nasional Manajemen Teknologi X Program Studi MMT-ITS, 2009.

[2] W. Gunawan and Suswati, "Pengolahan Limbah Domestik Dengan Teknologi Taman Tanaman Air (Constructed Wetlands)," Indones. Green Technol., vol. 2, 2013.

[3] Risnawati and Damanhuri, "Penyisihan Logam Pada Lindi Menggunakan Constructed Wetland," Bandung, 2009.

[4] A. Toscano, "Modelling Pollutant Removal In A Pilot-Scale Two-Stage Subsurface Flow Constructed Wetlands," Ecol. Eng., vol. 35, pp. 281-289, 2009.

[5] N. C. S. Rai U.N. Tripathi R.D., Singh N.K., Upadhyay A.K., Dwivedi S., Shukla M.K., Mallick S., Singh S.N., "Constructed wetland as an ecotechnological tool for pollution treatment for conservation of Ganga river," Bioresour. Technol., vol. 148, pp. 535 - 541, 2013.

[6] T. V. A. Akratos Chritos S., Papaspyros John N.E., "An artificial neural network model and design equations for BOD and COD removal prediction in horizontal subsurface flow constructed wetlands," Chem. Eng. J., vol. 143, pp. 96-110, 2009.

[7] M. Jason, "Constructed WetlandsTechnology Assessment and Design Guidance," 2007.

[8] R. Sherwood and C., "Subsurface Flow Constructed Wetlands For WasteWater Treatment," 1993.

[9] M. N. C. T. angustifolia L. Stevens, "Plant Symbol = TYAN. USDA, NRCS, National Plant Data Center c/o Department of Plant Sciences," 2006. 